\title{
Neonatal sepsis outbreak at the first maternity hospital of Ulaanbaatar
}

\author{
T Muugulug*, A Bat-Erdene, Ariungerel Bat-Erdene \\ From International Conference on Prevention \& Infection Control (ICPIC 2011) \\ Geneva, Switzerland. 29 June - 2 July 2011
}

\section{Introduction / objectives}

In-depth analysis for Neonatal sepsis outbreak at the first maternity hospital.

\section{Methods}

We conducted screening by clinical signs among the newborns and then collected clinical samplings from the suspected cases with environmental samplings. Bacteriological analysis was done for all the samples and agents were detected along with antibiotic resistance analysis.

\section{Results}

In Januaryof 2010, 21 neonatal infection cases with 2 death reported were screened by clinical signs. $76.2 \%$ of them had cesarean delivery and $23.8 \%$ were given normal birth. Clinical presentations were fever $100 \%$, cyanosis $76 \%$, breath distress $65 \%$, abdominal filling $59 \%$, abdominal vein unroll 53\%, hyperbilirubinemia 53\%, irritability $47 \%$ and rigidity $12 \%$. Clinical samplings gathered from 18 neonates and $12 / 66.6 \% /$ of them were detected multi resistant Klebsiella pneumonia.

there are collected 33 environmental swabs. $27.2 \%$ of them have culture positive, including staphylococcus with resistance to ampicillin, streptococcus with sensitive to vancomycin, gram positive and gram negative bacteria and micrococcus resistance to vancomycin. $25 \%$ of 8 swabs collected from mothers of 2 nd ward had culture positive, including enterococcus with resistance to vancomycin and bacillus cereus.

In air bacteriological sampling results determined 6 staphylococcus hemolyticus. 8 health care workers had Staphylococcus aureus in nasal swabs, 1 had streptococcus pneumonia and klebsiella pmeumonea which were

Dept. for Research and Surveillance of Hai, National Center for

Communicable Diseases of Mongoli, Ulaanbaatar, Mongolia detected from 5 neonates nasal swabs, blood and wounds.

\section{Conclusion}

The agents of the outbreak were Klebsiell?pneumonia and staphylococcus and transmission occured from person to person due to poor performanve of the relevant precautions. The increased workload of the staff, poor condition of the hospital building and sewage system were the supporting reasons of the outbreak.

\section{Disclosure of interest}

None declared.

Published: 29 June 2011

\section{doi:10.1186/1753-6561-5-S6-P96}

Cite this article as: Muugulug et al.: Neonatal sepsis outbreak at the first maternity hospital of Ulaanbaatar. BMC Proceedings 2011 5(Suppl 6):P96.

Submit your next manuscript to BioMed Central and take full advantage of:

- Convenient online submission

- Thorough peer review

- No space constraints or color figure charges

- Immediate publication on acceptance

- Inclusion in PubMed, CAS, Scopus and Google Scholar

- Research which is freely available for redistribution 